Dorothea Alewell, Katrin Bähring, Kirsten Thommes*

\title{
Institutional Structures of the Flexible Assignment of Personnel between Enterprises. An Economic Comparison of Temporary Agency Work, Interim Management and Consulting*
}

Temporary Agency Work, Interim Management and Consulting are three versions of the flexible assignment of personnel between enterprises, which are - with regard to their basic economic structure - more or less similar, but which are organised under thoroughly different contractual and legal regulations in Germany and in three more or less differentiated segments of the market. The paper aims at comparing these forms of flexible personnel assignment under empirical and institutional aspects from an economic perspective.

Key words: Interim Management, Consulting, Temporary Agency Work, Flexible Assignment of Personnel between Enterprises, Institutional Comparison, Economic Analysis

* Prof. Dr. Dorothea Alewell, Friedrich-Schiller-University Jena, Department of Economics, Chair of Business Administration, Personnel Management and Organisation and SFB 580, Project B5, Carl-Zeiss-Straße 3, 07743 Jena, Germany, phone: +49 (0)3641-943130, fax: +49 (0)3641-943132, e-Mail: D.Alewell@wiwi.uni-jena.de.

Katrin Bähring, Friedrich-Schiller-University Jena, Department of Economics, Chair of Business Administration, Personnel Management and Organisation and SFB 580, Project B5, Carl-Zeiss-Straße 3, 07743 Jena, Germany, phone: +49 (0)3641-945048, fax: +49 (0)3641-945052, e-Mail: katrin.baehring@wiwi.uni-jena.de.

Kirsten Thommes, Friedrich-Schiller-University Jena, Department of Economics, Chair of Business Administration, Personnel Management and Organisation and SFB 580, Project B5, Carl-Zeiss-Straße 3, 07743 Jena, Germany, phone: +49 (0)3641-945048, fax: +49 (0)3641-945052, e-Mail: kirsten.thommes@wiwi.uni-jena.de.

** Article received: July 17, 2005

Revised version accepted after double blind review: September 18, 2005. 


\section{Temporary agency work, interim management and consulting as re- lated forms of the flexible assignment of personnel between enterprises}

Temporary agency work, interim management and consulting are instruments with which it is possible to cover short-term manpower requirements and to outsource parts of the classical employer function simultaneously. ${ }^{1}$ These three instruments, used for outsourcing and improving flexibility ${ }^{2}$, are very similar with regard to their basic economic structure, but differ significantly in terms of their institutional design under German labour and social security law. These differences can be roughly described as follows for the prototypical use ${ }^{3}$ of these instruments:

For temporary agency work, clients act as borrowers and demand temporary rights of directive authority to the work capacity of people who are contractually employed by the temporary employment agency which acts as a lender. Thus there is a three-way relationship between the borrower (or client), the lender (temporary work agency) and the temporary agency worker (Purcell/Purcell/Tailby 2004). This relationship is comprehensively regulated by the German Law on Labour Leasing. Lender and borrower enter a labour leasing contract, which is a special of a contract of personnel service ("Dienstvertrag") which - according to German law - stipulates that the supplier owes the customer a specified service (but no guaranteed output or success). Between the temporary employment agency and the temporary agency worker an employment contract according to German Labour and Social Security Law is placed. Although there is no contractual agreement between the temporary agency employees and the client firm where they are deployed, the client acquires the temporary right of directive authority over the temporary agency workers through the labour leasing contract.

Interim management has a basic structure that is a very similar to temporary agency work. The company's demand for management services is short-term and planned as being temporary right from the start, too. In contrast to consulting the assignment includes implementation of instruments, directive authority within the client's hierarchy and budget responsibility. In contrast to temporary agency work the interim manager does not sign an employment contract with the interim management agency. Instead, they conclude a contract of personnel service ("Dienstvertrag") or (less frequently) a contract of a certain output ("Werkvertrag"). The latter stipulates that the supplier owes the customer the creation/production of a special work or output. Interim managers thus remain self-employed. In some cases, which are estimated to represent

1 The employer function is sourced out in that the customer firm does not sign an employment contract with the individual external employee.

2 This flexibility can relate to both time and costs. Particularly the flexibility regarding costs and the possibility to bring down costs are some of the main reasons to introduce temporary agency work. However, for the purpose of this paper this function of temporary agency work is not central, and thus in the following we will concentrate on other aspects of the instruments.

3 We are well aware that there are many hybrid forms between the prototypes we define in the following. We use them nevertheless to keep the analysis simple and clear. Please see below at the end of section one for further remarks on hybrid forms. 
about 15 to $40 \%$ of overall turnover (Gloger 2001, Kleff 2003), there is a three-way relationship as in temporary agency work, too: Over time, the interim manager works in various different client firms. One (or more) interim management agency (agencies) is engaged in placing the employee in these firms. The client enters a contract for a certain output (Werkvertrag) or of personnel service (Dienstvertrag) with the agency covering the procurement or placement-service.

There often is a three-way relationship for consulting, too. ${ }^{4}$ While the individual consultants are often contractually bound by consulting firms as employees, they work for various different clients, who have a temporary staff requirement concerning mainly analytical and conceptual tasks in management (and not primarily implementation tasks as in interim management). The clients do not enter directly into a contract of a certain output or a contract of personnel service with the individual consultants, but instead with the consulting firm, who acts as an intermediary. Based on the directive authority the consulting firm gained via the employment contract, it delegates the workers individually or as a team to the customer firm. Because of the employment contract, the consultants are employees and come under the German Labour and Social Security Law. A summary of the similarities and differences can be seen in Table 1.

Table 1: The institutional design of the three prototypes

\begin{tabular}{|c|c|c|c|c|}
\hline & & $\begin{array}{l}\text { Temporary } \\
\text { agency work }\end{array}$ & $\begin{array}{l}\text { Interim man- } \\
\text { agement }\end{array}$ & Consulting \\
\hline \multicolumn{5}{|c|}{ Form of the contract between .... } \\
\hline 1. & SP and client & LLC & $\mathrm{CPS}$ or $\mathrm{CCO}$ & $\mathrm{CPS}$ or $\mathrm{CCO}$ \\
\hline 2. & SP and worker & EC & $\mathrm{CPS}$ or $\mathrm{CCO}$ & EC \\
\hline 3. & worker and client & ------ & CPS or CCO & ------ \\
\hline \multicolumn{2}{|c|}{ Legal role of the SP } & $\begin{array}{l}\text { employer of the } \\
\text { worker }\end{array}$ & $\begin{array}{l}\text { placement func- } \\
\text { tion }\end{array}$ & $\begin{array}{l}\text { employer of the } \\
\text { worker }\end{array}$ \\
\hline \multicolumn{2}{|c|}{$\begin{array}{l}\text { Is the directive authority trans- } \\
\text { ferred from the SP to the client } \\
\text { firm? }\end{array}$} & yes & $\begin{array}{l}\text { no } \\
\text { (was not acquired } \\
\text { by the SP) }\end{array}$ & $\begin{array}{l}\text { no } \\
\text { (but was acquired } \\
\text { by the SP) }\end{array}$ \\
\hline \multicolumn{2}{|c|}{$\begin{array}{l}\text { Does the worker have budget or } \\
\text { directive authority within the hi- } \\
\text { erarchy of the client firm? }\end{array}$} & no & yes & no \\
\hline
\end{tabular}

$\mathrm{SP}=$ service provider,

LLC = labour leasing contract,

CPS $=$ contract of personnel service ("Dienstvertrag")

$\mathrm{CCO}=$ contract of a certain output ("Werkvertrag")

$\mathrm{EC}=$ employment contract

This demonstrates that the basic economic problem of the client - covering flexibly short-term quantitative and or qualitative staffing requirements without entering into (long-term) employment relations - is fundamentally similar for temporary agency

4 There are in fact consultants who offer their services as self-employed individuals. However, over $80 \%$ of the market volume is generated by medium-sized and large firms (BDU 2005). 
work, interim management and consulting. However, the institutional design within which this problem is managed is shaped very differently for each of the three forms.

In the following sections, the differences in the institutional design will be examined and explained based on an institutional economic analysis. To keep the analysis simple and clear, our analysis will concentrate on the prototypical cases that are currently predominant and which have already been sketched, although we are well aware that a whole range of hybrid forms exist and will further develop in the future.

Our question as to the institutional differences between temporary agency work, interim management and consulting will become even more meaningful in the future, due to several important developments:

Firstly, the German Law on Labour Leasing underwent various legal changes the last of which took effect as from January 2004. These strengthen the incentives for concluding collective wage agreements and have already resulted in an increase of the number and scope of collective agreements in temporary agency work, accompanied by a gradual increase of wage costs for temporary agency workers. It is therefore possible that the wage cost advantage of temporary agency work which existed until the end of 2003 will decrease or disappear in the future. It can be shown (Alewell/Friedrich/Martin 2004) that this development could well lead to a decrease in the temporary agencies' focus on lowly qualified workers and to an increase in temporary agency work that deals with highly qualified workers, ${ }^{5}$ as the central benefit of temporary agency work that persists when the wage advantage has been removed, i.e. the recruitment cost advantage, is particularly strong in relation to highly qualified workers. Temporary agency work can therefore be predicted to change significantly in Germany: temporary work agencies will reduce their engagement in the segment that has predominated up to now, namely, unskilled or semi-skilled work, and will shift their focus to highly qualified work, where the similarities of consulting, interim management and temporary agency work are quite strong (Alewell/Friedrich/Martin 2004).

Secondly, we do expect that the three markets we consider here will converge even more strongly in the near future. In practice, there are already large numbers of hybrid cases between the three prototypes we described above: On the one hand there is temporary agency work by highly qualified workers which is sometimes hard to differentiate from interim management. On the other hand there are both interim managers and temporary agency workers who are employed solely to complete conceptual tasks and therefore have more of a consulting-function rather than being responsible for putting those concepts into practice. In consulting, there are so-called "implementation consultants", who are responsible for putting things into practice as well as for conceptual work, and one question that has already been discussed is if and how the implementation of concepts should be considered as a central element of business consulting. However, up until now - and this is the classification that we will follow consultants and interim managers have often been classified under the understanding that in general, the former take on primarily conceptual and analytical tasks, while the

5 Since 1994, the number of specialists employed via temporary agency work has grown by $200 \%$, while the average growth of temporary agency work over this period was only $140 \%$ (Ernst and Young 2004). 
latter are directly responsible for implementation and have directive authority within the hierarchy of the adopting firm and are in charge of a budget. ${ }^{6}$ Although this demarcation of the typical task areas continues to decline, the institutional differences between these two fields are still very strongly defined. ${ }^{7}$

Thirdly, unemployment and restructuring have now reached the management levels and thus the question arises whether these forms of flexible personnel assignment could bridge the gap between unemployment and work for highly qualified persons as for lower-qualified persons in temporary agency work. Consequently, the economic role of the intermediaries in the labour market for highly qualified employees and managers will become more important.

The goal of this paper therefore is to identify factors which cause and explain the differences in institutional design between temporary agency work, interim management and consulting. In section 2 we present some empirical data relating to the three forms of flexible personnel assignment. The data provide a basis to assess the empirical plausibility of the theoretical considerations presented in section 3, which concern the differences in institutional design. Section 4 contains a short summary and shows where further research is required.

\section{Temporary agency work, interim management and consulting in Germany - some stylised empirical facts}

\subsection{Temporary agency work in Germany}

Data on the size of the market for temporary agency work are quite varied (e.g. Alewell 2005; Nienhüser/Matiaske 2003; Segal/Sullivan 1997). In the first half of 2004, there were 15,070 temporary work agencies in Germany (Federal Employment Services 2004). These had an average stock of 399,789 temporary agency workers. In 2002 , temporary workers made up $1.22 \%$ of all employees who are subject to social insurance contribution (IAB-Database on the internet, overview 3.8). The turnover of the temporary agency work sector was 7.5 billions $€$ in $2004 .^{8}$

Temporary agency workers are employed primarily in production $(34.84 \%)$ and unskilled work (32.18\%). 15.56\% were engaged in the services sector, $10.15 \%$ in sales and administration, $3.87 \%$ as technicians and 3.40\% in other occupations (Federal Employment Service 2005).

6 According to the classical definition of consulting, the consultant does not take any decisions for the firm, but is just an assistant to their own decision making. This means that the company retains the freedom, and also the responsibility, to make the decision as to how the consultant's advice should be carried out (o.V./Personalwirtschaft 1996). However, firms increasingly expect the realisation of the conceptual work to be carried out as well (Schaudwet 2003, Fink 2004).

7 Beside the difficulties in classification which have been described, it should also be mentioned that there are further types of intermediaries in the markets for temporary agency work and consulting who simply advice the potential clients which temporary work agency or which consulting firm would be appropriate for them.

8 This was an increase in market volume of about $36.4 \%$ in comparison to the previous year (Lünendonk 2005) as well for further information about market structure etc. 
The duration of assignment to client firms is generally short, with $75 \%$ of all temporary agency workers working less than three months for one client (IAB 2004a). Only about $5 \%$ of temporary agency workers are assigned to one client for longer than one year (Bellmann/Dahms/Wahse 2004). Only about 40\% of the employment contracts between workers and work agencies endure for more than three months. Data from the employment statistics of 1997 show that only $15 \%$ of newly employed temporary workers stayed for longer than one year with their employer, compared to $75 \%$ in the economy as a whole. ${ }^{9}$ Additionally, approximately $15 \%$ of the workers are employed by former clients of the work agency after resigning from their temporary work assignments. ${ }^{10}$ Therefore it can be assumed that labour turnover is much higher among temporary agency workers as in other sectors of the labour market.

In West Germany (East Germany) in 2001, the average monthly income of men between the ages of 25 and 35 who were employed as full-time temporary agency workers reached about $60 \%(70 \%)$ of the average monthly income of the respective group of workers from all sectors. These wage differences tend to be more significant for lowly qualified temporary agency workers than for highly qualified temporary agency workers. ${ }^{11}$ Resulting from the collective wage agreements that were induced by the changes in the labour law for temporary agency work, wage relations will probably have shifted in the meantime. However, since these changes have only been in force since January 2004, up to now there are no annual data available yet from which clear and comprehensive conclusions can be drawn.

Within temporary agency work, the hourly wage is very varied. The German Association of Private Employment Agencies' (BZA) collective wage agreement stipulates hourly rates between $6.85 €$ and $15.50 €$, resulting in yearly incomes for temporary agency workers of between $14,248 €$ and $32,240 €$. In addition to the gross earn-

9 Data based on the temporary agency worker statistics of the Federal Employment Service, (Jahn/Rudolph 2002).

10 Results from the Business Panel of the IAB (IAB 2004b). Other sources list higher assumption rates of around one third (Bundesverband Zeitarbeit 2002; Streicher/Lünendonk 2002; Jahn/Rudolph 2002).

11 The wage relationship was $60 \%$ in West Germany in 2001 for blue-collar workers and $71 \%$ for white-collar workers; in East Germany, this was $73.5 \%$ and $83.5 \%$ respectively (Jahn/Rudolph 2002). The literature overview by Nienhüser/Matiaske (2006) shows furthermore that there was a wage differential between permanent staff and temporary agency workers of between $22 \%$ and $40 \%$ in Germany in 2002, with the wages of the temporary staff being lower than those of the permanent staff members. Temporary agency workers were also significantly worse off than other employees with regards to other employment conditions (Nienhüser/Baumhus 2002). These results are also confirmed by anecdotal evidence as recounted by staff managers of temporary work agencies in private conversations: for example, they state that one of their problems in the industrial sector is to stop employers from making the temporary agency workers work under more straining conditions than the permanent staff. Deviating from this, the wage penalty in the US seems to be smaller. Segal/Sullivan (1998) detected a differential of $10 \%$. 
ings of the temporary agency worker, the client firm carries further costs equivalent to around $30 \%$ of the worker's hourly wage. ${ }^{12}$

\subsection{Interim management in Germany - an empirical approximation}

There are hardly any valid, independent empirical studies on interim management in Germany. The existing estimations and empirical data are mainly issued by parties within the sector ${ }^{13}$, and should therefore be interpreted cautiously. For want of better data, the following section will nevertheless summarise the available "empirical speculation" in order to illuminate the - nevertheless still fuzzy - picture of the interim management market in Germany.

There are about 30 interim management agencies in Germany. ${ }^{14}$ With regard to the number of interim managers, figures of up to 30,000 (Meinking 2005) are often quoted. However, these estimation probably represent a significant exaggeration of the number of effectively active interim managers. ${ }^{15}$ Estimates which indicate that the number of permanently active interim managers is around 1,000 or 1500 appear more realistic.

The market volume for interim management in Germany was estimated to be 400 million $€$ in 2004 (DDIM 2005). ${ }^{16}$ Of this market volume in total, about $15 \%$ to $40 \%$ is recruited through agencies, while the larger share of total turnover is generated by independently acting interim managers (Gloger 2001; Kleff 2003).

The most important reasons for interim manager assignments are the need for restructuring or crisis management (34\%), project management $(17 \%)$, coaching $(14 \%)$, covering additional requirement of management personnel $(13 \%)$, covering vacancies (9\%) or partnership changeover (7\%) (o.V./Food 2003; Heuse 2002; Klinkmann 1996). The duration of typical interim management assignments ranges between 3 months and one year with an average duration between 3 and 9 months (Dreesen 1994; Gloger 2003). In general, the interim managers have gathered 15 to 20 years of

Information according to Mr Hellmers from Bindan Ltd. from a phone conversation dating the 4th of July 2005.

13 In particular, the Society of German Interim Managers (DDIM) and Ludwig Heuse Ltd, a large supplier of interim management services.

14 According to DDIM (2005), 25 to 30 professional placement agents are active on the market and have access to pools of interim managers. A further 30 to 40 enterprises present themselves on the market as "placement agents", but have yet to prove that they really are in the business.

15 Other estimations range between 1,000 to 1,200 active interim managers (Westhoff 2004), 5000 active interim managers for the early 1990s (Baumeister 1993) and numbers of up to ten times as many who try to enter business (Jürgens 2000; Kalt 2000). The DDIM (2005) estimates that the number of currently active professional interim managers in Germany is about 1,500 . A further 7,000 to 8,000 people include the term "interim manager" in their job title, but are actually more accurately considered as consultants or "work seeking" (Kalt 2000).

16 For the years 1999 to 2001, the market volume was still around 80 to 140 million $€$. (Bloemer 2002; o.V./Finance 2002). 
professional experience before their first assignment, which is why the majority of interim managers is more than 40 years of age (Bloemer 2003, DDIM 2005). Concerning the price structure in the market, it is estimated that interim managers earn an average day rate of 1,250 € (König/Schönfeld 2005, Management Angels Ltd 2004). According to Management Angels Ltd (2004), day rates of more than 1,750 € are only paid in $2 \%$ of cases. The agencies' placement fee ranges between $25 \%$ and $30 \%$ of the interim manager's total fee (Thum 1998, Baumeister 1993). The capacity utilisation level can be estimated between $61 \%$ and $85 \%$ (Kalt 2000, Alewell 2005). This results in an estimated annual income of $125,000 €$ to $140,000 €$ (Kalt 2000, Alewell 2005).

\subsection{Consulting in Germany - some stylised facts}

There is a considerable stock of information on the consulting market in Germany, much of which is released by the Federal Association of German Management Consultants (BDU). The German market for business consulting covers a total of 67,300 consultants who are employed in about 14,300 suppliers in classical consulting market sectors such as strategy, organisation, management and marketing (o.V./Handelsblatt 2005). In 2004, the market turnover was 12.3 billion $€$ (BDU 2005).

Consultants are employed in various sectors, the main areas of which are organisational consulting $(35.5 \%)$, IT consulting $(24.5 \%)$ and human resource management $(11.5 \%)$ (BDU 2005). The main content of the consulting tasks is process optimisation (70\%), followed by strategic reorientation (51\%) (Lichter/Tödtmann 2004). The duration of consulting projects varies according to their content from a half-day to 4 weeks (methodical support) or even 24 months (body leasing) (Petmecky/Deelmann 2004).

There are various seniority levels within consulting firms (Petmecky/Deelmann 2004). The individual consultants are often assigned in team structures, in which junior consultants are paired up with senior consultants. Career advancement within the consulting firm works according to the "up or out" principle, where the consultant either climbs the next step of the ladder within a certain time frame or else must leave the firm. Entries as to the duration of employment relationships are not available to us. But an average of $28 \%$ of consultants in large consulting firms is said to be willing to transfer into jobs in client firms, and in some very large consulting firms this proportion is said to be more like 50\% (Engeser/Schaudwet 2004). If these figures are correct, this, together with the up-or-out principle, could result in high fluctuation levels in consulting firms. According to Friedrichsen (2005), junior consultants without any experience earn between 47,256 € and 56,190€, senior consultants with more than five years of experience earn between $62,338 €$ and $65,523 €$ and partners with more than 10 yeas of experience earn between $102,240 €$ and $162,020 €$ annually.

\subsection{Summary of the most important stylised facts}

The temporary agency work market is a large market with 7.5 billion $€$ yearly turnover. Temporary agency work is characterised by the fact that employees come under the protection of the Labour and Social (Security) Law. Although they earn significantly less and in general work under worse conditions than permanent employees in comparable positions, the assignment risk is borne by the temporary work agency for the duration of the employment contract. A large proportion of employment contracts 
end after a short period of time. For about $15 \%$ of employees, temporary agency work constitutes a bridge into the first labour market. Enduring worse working conditions in temporary agency work in the short-term can be interpreted as an investment to gain a permanent position with one of the client firms. The placement of temporary agency workers regularly occurs through temporary work agencies.

The market for interim managers is relatively small, with only about 400 million $€$ in annual turnover. The interim managers are self-employed and do not come under the protection of the Labour and Social Security Law. With regard to fixed and variable salary components (and without accounting for social security contributions) they earn more than permanent staff in comparable positions in the hiring firm. Little is known about other working conditions. Their utilisation rate lies on average between 60 and $70 \%$, so there is a considerable assignment risk. Transfers into permanent positions are - apparently - the exception rather than the rule, although data on this aspect are very weak. Agencies are only involved in 15 to $40 \%$ of interim manager placements.

The consulting market is the largest market we consider here, with 12.3 billion $€$ in annual turnover. Most consultants (apart from the partners) are bound to the consulting firm by an employment contract and therefore also come under the labour and social security law. As for temporary agency work, the employer bears the assignment and employment risk. Day rates, which are paid to the consulting firm, often range between approximately 1,875 to 2,500 €, and are thus 50 to $100 \%$ higher than those for interim managers (König/Schönfeld 2005). Transfers of consultants to permanent positions in client firms occur relatively often.

\section{An institutional economic comparison of temporary agency work, interim management and consulting}

In this section, the question which determinants help to explain the central differences in institutional design between temporary agency work, interim management and consulting is analysed. We summarise and clarify the institutional differences in section 3.1., discuss the differences concerning the transfer of directive authority to the client in 3.2. and the differences concerning the role and function of the service providers as market intermediaries in section 3.3 .

\subsection{Institutional differences between temporary agency work, interim management and consulting}

There are two main differences in the institutional design between the three forms of flexible assignment of personnel between enterprises. One significant difference between the fields we consider here is that temporary agency workers are subject to the directive authority of the hiring firm (of the client) through the labour leasing contract. Interim managers and consultants on the other hand are engaged under contracts of a certain output or of a personnel service with the client. Thus directive authority is not transferred to the client. While interim management agencies have never "purchased" this authority right in the first place, consulting firms have acquired the directive authority in the employment contract with the individual consultant and could, in principle, also transfer this right to their clients. These differences in the contractual structure are particularly interesting, as - for interim managers and consultants 
- significant and strategically sensitive management work is done by "external" staff who are not subject to the client firm's directive authority. While the assignment of external staff in areas where the tasks are relatively simple and the necessary qualifications are lower may be interpreted as a more or less standard procedure, and while this is common for consultants who tackle analytical and conceptual tasks without implementation or budgetary responsibility, the assignment of interim managers as external staff to the upper management levels of a company where they do exert directive authority over personal and other resources of the client firm is quite surprising prima facie. We will analyse these differences in section 3.2.

The second difference relates to the role that intermediaries - temporary work agencies, interim management agencies and consulting firms - play in the labour market. Here, and in contrast to the aspect just discussed, there are strong similarities between temporary work agencies and consulting firms: Both intermediaries take on the - economic and juridical - employer function. Interim management agencies in contrast do not act as employers and do not enter into employment contracts with the interim managers but concentrate on the placement function. These differences in the role and economic function of the service providers are analysed in section 3.3..

\subsection{An institutional analysis of differences regarding the transfer of directive authority}

A central argument regarding the application of employment contracts as basic frame contracts which give the employer directive authority over the capabilities of the employee states that employment contracts are the most efficient types of contracts in situations with significant environmental uncertainty and complexity (Williamson/Wachter/Harris 1975). Given these environmental conditions, the exact ex ante specification of the work required could only be achieved by incurring very high transaction costs. The directive authority allows the employer to establish ex post which tasks are required and what should be achieved at a certain point of time (Williamson/Wachter/Harris 1975).

This reasoning is directly persuasive in situations where tasks of low complexity are to be achieved and the supervisors (e.g. the employer) have enough information and insight into the situation to direct subordinates. However, the higher the hierarchical level and the more specialised the skills and knowledge of the employee in comparison to their respective supervisors or the employer, the less often the coordination of tasks is undertaken through specific and concrete instructions and the more often this occurs through defining objectives. Since under these conditions supervisors will rarely have the necessary knowledge, opportunity or time to give individual instructions, an efficient division of labour between highly qualified workers with heterogeneous human capital stocks systematically results in management by objectives. If goals and objectives have been formulated sufficiently general, they may remain constant under changing situational conditions, thereby proving much more suitable than specific instructions if there is significant environmental uncertainty and complexity. Thus clients of temporary work agencies might efficiently utilise the directive authority to co-ordinate the predominantly simple tasks of the temporary agency employees they rented. However, the client's or employers right of directive authority 
cannot be substantiated as a necessary component of the "employment" contract for complex management tasks in consulting or interim management. Thus, short- or long-term contracts of a certain output or of personnel service with self-employed managers or consultants may be used efficiently, as goals and aims can be formulated in these contracts.

\subsection{An institutional analysis of the economic role of the different service providers}

Service providers adopt various roles as intermediaries in the labour market: while temporary work agencies and consulting firms normally (and always in the "prototypic" standard cases we are examining) employ their staff through employment contracts, interim management agencies generally only adopt a placement function so that the interim managers themselves remain self-employed.

\section{Preliminary remark: self-employment of interim managers as fraudulent evasion of labour and social security law?}

Prima facie the contractual structures in interim management could be interpreted as a more or less fraudulent evasion of the German labour and social security law. Due to the fact that (interim) managers are less subject to directive authority than temporary agency workers, their status as employees in the German labour and social security law is more easily negated. Furthermore, on average there are probably only weak incentives for all the affected parties to enter into an employment contract. Thus, interim management agencies could evade the employer function with all its related costs and shunt interim managers into self-employment.

There are, however, two important arguments which rebut this interpretation: Firstly, exactly the same arguments would apply for consulting. In this market segment we observe a whole range of medium to large consulting firms with more or less permanent employees alongside with a large number of self-employed consultants. Secondly, significant differences in institutional structure can be reconstructed by economically explaining the adoption of employer functions by temporary work agencies and consulting firms and their non-adoption by interim management agencies.

\section{Differences in the service providers risk allocation and pooling functions}

Temporary work agencies and consulting firms are employers who bundle multiple short-term - and potentially also heterogeneous - employment relations into mid-term continuous employment contracts that tend to endure longer than the individual assignments. Of the three service providers we consider, only interim management agencies do not adopt this function.

The size of the market and homogeneity of demand in one important explaining factor: Due to the small market size and the even more heterogeneous demand structure in the interim management field, it would be much harder for the agencies to achieve a reduction in the assignment risk for the interim managers by bundling various short-term assignments into longer-term employment opportunities than it is for temporary work agencies or consulting firms, who act in much larger markets and therefore face a larger number of more similar or comparable mandates. These differ- 
ences make it easier for temporary work agencies and consulting firms than for interim management agencies to calculate the demand for services and therefore to derive their staff requirements (particularly in the classical qualification segments of metal workers, electricians, welders, office assistants etc. for temporary work agencies, and in classical consulting areas such as IT-consulting, organisational and strategic consulting in the consulting firms). ${ }^{17}$

\section{Differences relating to the employers' selection and qualification functions}

Before an assignment starts, there generally exists an information asymmetry between the employer and the workers or managers with regard to their skills, knowledge and commitment, which results in the application of various selection instruments, for example signalling or screening measures. All three service providers we consider can more or less reduce the recruitment and selection costs of their clients by establishing a pool of capable workers through which they can recruit more quickly than the individual client.

However, this information asymmetry has differential effects in the three fields of flexible assignment of personnel we scrutinise: It poses a more serious problem where entrepreneurial qualifications are required for implementation tasks in management than for purely technical or non-management tasks and for analytical and conceptual tasks. For interim management tasks which are - in contrast to the prototypical classical consulting tasks we analyse - not restricted to the conception and analysis of issues, but include the implementation aspect of management the determining factors of a person's success or relative contribution are not only their technical or analytical qualifications (which are comparatively easy to discern), but also a whole range of extrafunctional qualifications (social and extra-professional competencies, skills and knowledge), which are much harder to measure. Micro-political finesse, long-run ability to get the job done, people knowledge, the ability to establish trust in relationships, conflict skills, physical and psychological toughness and other similar qualities all belong to this group. In addition, high levels of implicit knowledge regarding the influencing of other people, certain people types and the control and supervision of change processes in the client firms will all play a role for the success of managers with implementation responsibilities. If managers have implementation and budget responsibilities and directive authority over other employees, inappropriate appointments are particularly costly because of their "leverage effects" via other employees' work. Thus the manager's personal fit into the value system of the client firm will play a much more significant role. Such skill components are often of a much more implicit nature then analytical and conceptual skills needed in consulting. As a consequence of these different skill profiles, the different types of service providers apply differential selection instruments:

Temporary work agencies and consulting firms undertake the screening of potential coworkers by using classical staff selection instruments such as, for example, analysing a person's C.V. and application documents, and interviews. Furthermore, they apply

17 Kvasnicka (2003) shows empirically how efficiently temporary work agencies utilise their pool of workers. 
various short-term placements in customer firms as tests instruments. Due to the simple structure of the majority of tasks performed by temporary agency employees, their work can generally be assessed relatively quickly and easily. Most labour leasing contracts provide a clause stating that a replacement worker will be assigned straight away if the screening result is negative. Very few negative reports can lead to the temporary agency employee being removed from the temporary work agency's database and worker pool. Thus, temporary work agencies can achieve cost savings in selection and recruiting as market intermediaries (Alewell/Friedrich/Martin 2004).

Consulting firms can also use the above mentioned selection instruments effectively to screen for analytical and conceptual skills. Additionally, young and newly employed consultants are often incorporated into teams with experienced consultants. This team structure provides on the one hand a continuous monitoring of their performance and on the other hand the opportunity to determine easily and reliably the respective strengths and weaknesses of individual employees. Thus, ongoing selection benefits can be realised. Besides this selection function, the team principle supports a specific development and human capital effect. New consultants whose knowledge of general methods and know-how is theoretically up-to-date but has not yet been enriched through actual experience and practice are put into a team with experienced consultants whose education may date significantly further back, but who have richer experience in applying their knowledge and skills and have valuable knowledge about specific methods and analytical tools the consulting firm has developed. Thus, a bilateral development effect may occur in the consulting teams - young consultants contribute up-to-date general knowledge, while experienced senior consultants provide varied implementation skills and firm-specific analytical tools. An important function of the consulting firm as employer thus is the efficient combination of individual specialised stocks of human capital.

These development and selection effects can greatly benefit from a systematic coordination of team structure. Summarising, consulting firms enter employment contracts and acquire the directive authority over their employees to internally optimise the group structure, and with it selection, allocation and development of the consultants. In contrast to this, temporary work agencies acquire the directive authority with the central aim of transferring it to their clients, that is, for external use. Consulting firms can thus build advantages relative to their clients with regard to selection, combination of heterogeneous human capital bundles and development functions through the institutional structure of their employees' assignments.

Interim management agencies can not improve selection as much as temporary work agencies and consulting firms due to the special characteristics of implementation related management tasks, which have already been presented. Although interim management agencies can also appropriate numerous selection competencies just as other service providers, and although the classical selection instruments are equally available to them, these instruments predicate less about the management and entrepreneurial qualifications that are relevant for interim management and about the candidate's personal fit in the organisation than they do about their technical or professional knowledge. In this respect, the decision to be made by the management of the client is much 
harder to delegate to the interim management agency than to consulting firms and temporary work agencies.

Additionally, short term "test" assignments of just a few days are - in contrast to temporary agency work - not applicable due to the high complexity of the management role and tasks, the relatively long period of time it takes for someone to familiarise with the job, the greater strategic importance of the tasks and the fact that the most important effects of management decisions can often only be discovered in the long run. Interim management agencies can thus realise smaller selection benefits relative to their clients as the two other types of service providers.

Selection in interim management can often be realised more effectively via personal recommendations through networks than via the use of standardised selection instruments. As a result, agencies are often not used to intermediate and if they are still used, they concentrate on providing contacts (and on pre-selection of interim managers, e.g. for areas of experience). In contrast to the other two types of service providers, they do not build up a pool of permanent, pre-selected staff, who are then "lent" directly to the clients. The fact that only around 15\% to $40 \%$ of interim management assignments are arranged by agencies (while the rest is organised through the personal acquisition-activities and networks of the individual interim manager) demonstrates the limited economic function of interim management agencies in selection and development in comparison to consulting firms and temporary work agencies.

\section{Self-employment of interim managers as a quality signal}

This reasoning poses the question of how the selection problem is to be solved in the market for interim mangers. Our hypotheses is that the self-employment of interim managers, which is accompanied by assuming entrepreneurial risk, is a signal of their entrepreneurial skills, which are hard to determine through screening measures.

Self-employment can only be an efficient signal for the quality of entrepreneurial skills if there is a negative correlation between the relevant signalling costs on the one hand and the quality of the characteristics to be signalled on the other hand (Spence 1975, Milgrom/Roberts 1992, Baron/Kreps 1999). "Low quality" interim managers must have higher signalling costs than "high quality" interim managers (Ehrenberg/ Smith 2000).

Signalling costs in this case are the potential costs of self-employment, in particular lost income due to involuntary unemployed periods or low attainable day rate. Persons with low interim management qualifications will complete significantly less projects than people with higher qualifications, because they will more often be prematurely replaced or the assignment will be cut short. Moreover, even for completed assignments, they will - on average - not be able to provide as many good references as persons with higher management qualifications. Thus, self-employment will - on average - lead to a smaller number of assignments, a smaller rate of utilisation and a worse reputation for managers with lower interim management skills than for persons with higher skills. As a result, the signalling costs of the first group should be higher.

If the interim managers were to be permanently employed (as the employees of consulting firms and temporary work agencies), the interim management agency 
would bear the risk of non-assignment or of assignments at low daily rates. The signal concerning the entrepreneurial skills of the interim manager would be weakened.

Self-employment as a signal of entrepreneurial quality is not perfect, as involuntary unemployment can be the driving force of entering the interim management market. However, the signal is supported by the high relevance of references in the market and by the managers' possibility to offer their work capacity in other segments of the labour market. Involuntary interim managers with low interim management qualities and high signalling cost (who entered, for example, the interim management market due to unexpected unemployment), may have strong incentives to leave the interim management market and apply for permanent employment on lower hierarchical levels, if they can't collect good references. They may have acquired enough financial assets to stop gainful employment, too. References and outside options thus reinforce the signalling cost differences from self-employment.

This interpretation of self-employment as a quality signal is supported by anecdotal evidence from practitioners' reports in literature (Rüpprich 1997, Bloemer 2003). There, a lot of emphasis is placed on the importance of self-employment of interim managers, and it is stated that self-employment and varied assignments in different client firms have become part of the occupational image of interim managers. Additionally, several years' of previous experience as permanent or line manager and the respective references are often used as prerequisites to be entered to an agencies' pool of available interim managers. Thus, self-employment can not be an invariant personal need or characteristic of interim managers. Obviously, self-employment only becomes important as a signal once the managers start to work as interim managers.

Furthermore, it is reported (Bloemer 2003) that interim management contracts often contain a clause which provides the interim management agency with a placement commission in the case of permanent employment of an interim manager by a client. This fact does not fit with the proposition that self-employment is more or less the elixir of interim managers: If this were to be the case, such contract clauses would not be necessary at all. At the same time, strong hesitancy is very noticeable in conversations and interviews with interim mangers with regard to the question of whether transitions of interim managers to positions as employed managers occur more or less frequently. In contrast, the transition of temporary agency employees to permanent positions with clients following a temporary assignment occurs quite frequently and constitutes the so called "bridging function of temporary agency work" between unemployment and the first labour market. In consulting, too, a continuation of the career of the consultant in one of the former client firms is explicitly normal and even institutionalised to some extent in the so-called "up-or-out"-promotion-principle.

Lastly, the importance of good references and a good reputation for continued successful project completion is strongly emphasised in the literature (Schwertfeger 2005, Dreesen 2004, Witt 1987), and the problem of starting as an interim manager in the market without having previously acquired good references is reported. By contrast, in the general human resources literature, the significance of references is often questioned because of the legal requirements based in labour law relating to the writing of these references. While individual references do not play an exorbitantly important role for temporary agency work and consulting, they are very important in the 
field of interim management. This also fits with our hypothesis of the signalling effects of self-employment, because the possible refusal to write a positive individual reference is an important means of causing signalling costs for low quality interim managers.

This explanation of self-employment by its function as a quality signal also seems plausible when we consider the differences in institutional design between interim managers and the (special) group of highly qualified temporary agency workers, for example, engineers in research and development. For this group, the large majority of their work is co-ordinated via management by objectives and not via directive authority. From a labour law perspective, they could just as much be qualified as selfemployed as management staff. The same is true of consultants. However, if it applies that - compared with management tasks and skills - their qualifications are easier to establish through professional screening, educational credentials and through team work and easier to test directly once they start working on a task, then selfemployment as a signal is of much less importance for consultants and for temporary agency workers (even if the latter are highly qualified), because the information asymmetries are more related to technical and analytic-methodical aspects and can be overcome through screening.

\subsection{Summary: Systematic variation in institutional design}

Summarising section 3 of this paper, an overview of our results is presented in Table 2.

Table 2: Results of the institutional comparison

\begin{tabular}{|l|c|c|c|}
\hline & $\begin{array}{c}\text { Temporary } \\
\text { agency work }\end{array}$ & $\begin{array}{c}\text { Interim } \\
\text { management }\end{array}$ & Consulting \\
\hline $\begin{array}{l}\text { Placement function of the service } \\
\text { provider }\end{array}$ & yes & yes & yes \\
\hline $\begin{array}{l}\text { Employer function of the service } \\
\text { provider (according to law) }\end{array}$ & yes & no & yes \\
\hline $\begin{array}{l}\text { Transfer of directive authority to the } \\
\text { client (see chapter 3.2) }\end{array}$ & yes & no \\
\hline $\begin{array}{l}\text { Economic functions of the service } \\
\text { provider (see chapter 3.3) }\end{array}$ & & no & yes \\
\hline $\begin{array}{l}\text { 1. Risk allocation and } \\
\text { pooling function }\end{array}$ & yes & hardly developed & yes \\
\hline 2. Selection function & hardly developed & hardly developed & yes \\
\hline 3. Development function &
\end{tabular}

Differences relating to the acquisition and transfer of directive authority as well as the functions of the service provider can be explained as follows. Temporary work agencies acquire - via employment contracts - directive authority and transfer it to their clients, who use it to adapt to an uncertain environment and minimise transaction costs. The service provider fulfils a pooling function in the market and minimises selection cost at the same time. Consulting firms acquire directive authority, too. However, they don't transfer it to their clients, but use it to optimise internal personnel development and human capital profiles as well as selection and monitoring functions - elements where 
they realise advantages compared to their customers. The service provider adopts a pooling function in the market and minimises selection cost at the same time.

Interim management agencies do not acquire directive authority and thus cannot transfer it to their clients. They concentrate on pure placement (and pre-selection) functions, but adopt neither a pooling and risk allocation function nor strong development functions.

\section{Summary and research needs}

The central results of the analysis were already summarised at the end of sections 2 and 3 and will not be repeated here. As shown above, we can explain the institutional differences between temporary agency work, interim management and consulting considering some aspects related to the use of employment contracts on the one hand and based on the solution of various fundamental human resources problems on the other hand. In particular, risk allocation, selection effects and personnel development contribute to the different institutional designs in the three areas of flexible personnel assignments between enterprises.

We have simplified our analysis by only considering the typical, most frequently occurring types of work assignment, the necessary skills and knowledge and the typical differences in institutional design (only the "prototype" forms of the flexible assignment of employees between firms). In practice, a whole range of hybrid forms has been developed and in many individual cases, the sharp cut boundaries between the individual forms of flexible labour assignment among firms that are arranged or even contracted through an intermediary dissolve. If these developments continue, it will be interesting to observe the resulting shifts and developments in institutional structures on the market for personnel services.

There is a need for further research in various areas. The deficit in valid empirical data is very high. One is frequently forced to resort to rough estimations and speculations to determine the plausibility of various theoretical ideas. The largest research deficit, in our opinion, exists in interim management. For example, the differences between the assignments of interim management that are arranged through agencies and those that are not have hardly been explored yet. We expect that personal networks play a major role in this regard. There is an urgent need for research regarding incentive structures and selection of external staff in the management field as well, as it has hardly been examined if, beside the fixed day rates of interim managers and consultants, other forms of wage compensation which provide stronger incentives could and should be used.

\section{References}

Alewell, D. (1993): Interne Arbeitsmärkte. Eine informationsökonomische Analyse. Berlin: E. Schmidt.

Alewell, D./Friedrich, D./Martin, S. (2004): Gleichbehandlungsgrundsatz: Ende der Zeitarbeit? Ausgewählte betriebliche Wirkungen der Zeitarbeit aus ökonomischer Perspektive. In: Köhler, C./Struck, O. (2004): Beschäftigungsstabilität im Wandel: 227-245. München/Mering: Rainer Hampp Verlag.

Alewell, D. (2005): Zeitarbeit und Interimsmanagement in Deutschland - Ein empirischer und institutioneller Vergleich. Discussion paper 3/2005 of the SFB 580, Jena/Halle.

Baron, J.N./Kreps, D.M. (1999): Strategic Human Resources - Frameworks for General Managers. New York: John Wiley \& Sons. 
Baumeister, R. (1993): Manager auf Zeit für komplexe Fälle. In: Der Arbeitgeber, 45(24): 944-945.

BDU (2005): Facts \& Figures zum Beratermarkt 2004, Bonn.

Bellmann, L./Dahms, V./Wahse, J. (2004): IAB-Betriebspanel Ost - Ergebnisse der achten Welle 2003 Teil II. IAB Research paper, No. 3/2004.

Bloemer, V. (2002): Interim-Management: Chance zur Krisenbewältigung. In: HR Services, 1(4-5): 70.

Bloemer, V. (2003): Interim Manager. Berlin/Regensburg: Metropolitan Verlag.

Bundesagentur für Arbeit (2004): Arbeitsmarkt in Zahlen - Arbeitnehmerüberlassung. Nürnberg.

Bundesverband Zeitarbeit (BZA) (2002): Der Bundesverband Zeitarbeit Personaldienstleistungen informiert: Eckpunkte der Zeitarbeit für die Arbeitsmarktpolitik. URL: http://bza.de/eckpunkte.htm (From: 31.07.2002).

DDIM (2005): Interim Management in Deutschland - Die Zukunft der Arbeit ist flexibel. URL: http://ddim.sitepark.com/service/marktinformationen/markt.php, (From: 12.07.2005).

Dreesen, K. (1994): Das Modell des Management auf Zeit setzt sich durch. In: Blick durch die Wirtschaft, 20.05.1994.

Dreesen, K. (2004): Selbstmarketing des Interimsmanagers als Unternehmer in eigener Sache. In: Tiberius, V.A. (Hrsg.): Interimsmanagement. Bern et al.: Hauptverlag.

Ehrenberg, R.G./Smith, R.S. (2000): Modern Labor Economics. New York: Reading.

Engeser, M./ Schaudwet, C. (2004): Unternehmensberatung. Neue Ufer. In: Wirtschaftswoche, 15.04.2004: 71.

Ernst \& Young (2004): Personaldienstleistungen in Deutschland, Düsseldorf.

Fink, D. (2004): Management Consulting 2004 - Trend und Kompetenzen in der Managementberatung. Informationen zur Studie, Wissenschaftliche Gesellschaft für Management und Beratung mbH.

Friedrichsen, H. (2005): Gehaltsreport. Was Unternehmensberater verdienen. In: Spiegel online, URL: http://www.spiegel.de/unispiegel/geld/0,1518,348688,00.html (From: 12.07.05).

Gloger, A. (2001): Profis im Jobhopping - Interimsmanagement. In: Manager-Seminare, Vol. 48): 37-45.

Gloger, A. (2003): Sie kommen, um zu gehen. In: Die Welt, 05.07.2003.

Heuse, L. (2002): Interim Mangement: how does it differ from the search industry? In: Search-Consult, 11: $18-20$

IAB (2003): Die Zahlen-Fibel. URL: http://www.iab.de/asp/fibel/default.asp, 15.02.2003 (From: 12.07.2005).

IAB (2004a): Betriebliche Flexibilität 2003, Ergebnisse aus dem Betriebspanel. URL:

http://doku.iab.de/betriebspanel/Ergebnisse/2004_07_02_04_Betriebliche_Flexibilitaet_2003.pdf (From: 05.07.2005).

IAB (2004b): Übernahme von Leiharbeitern in die Stammbelegschaft, Ergebnisse aus dem Betriebspanel des IAB. URL:

http://doku.iab.de/betriebspanel/ergebnisse/2005_01_01_04_uebernahme_von_leiharbeitern.pdf (From: 05.07.2005).

Jahn, E./Rudolph, H. (2002): Zeitarbeit - auch für Arbeitslose ein Weg mit Perspektive. IAB-Kurzbericht No. 20/2002.

Jürgens, M. (2000): Gastspiel auf der Chefetage. In: Welt am Sonntag, 30.04.2000.

Kalt, H.G. (2000): Schnell einarbeiten, selbständig entscheiden - und gerne wieder gehen. In: Frankfurter Allgemeine Zeitung, 11.03.2000: 67

Kleff, C. (2003): Einsatz in Nadelstreifen. In: Handelsblatt, 30.05.2003.

Klinkmann, W. (1996): Interim-Management. In: Internationales Gewerbearchiv. Zeitschrift für Kleinund Mittelunternehmen, 44: 193-203.

König, A./Schönfeld, H. (2005): Wenn der Chef ,jobbt“. In: io new management, 10(4): 14-19.

Kräkel, M. (1997): Ökonomische Analyse der betrieblichen Karrierepolitik. München/Mering: Rainer Hampp Verlag.

Kräkel, M. (2004): Organisation und Management, 2. Edition. Tübingen: Verlag Mohr Siebeck.

Kvasnicka, M./Werwatz, A. (2002): Lohneffekte der Zeitarbeit. In: DIW-Wochenbericht, No. 49/2002, Berlin: 1-10.

Kvasnicka, M. (2003): Inside the Black Box of Temporary Agency Work. Discussion-Paper at the Center for Applied Statistics and Economics (CASE), No. 43/2003, Humboldt-Universität Berlin.

Lazear; E.P. (2004): Firm-Specific Human Capital: A Skills-Weights Approach. Discussion Paper Hoover Institution and Graduate School of Business, Stanford University, revised version January 2004. 
Lichter, J./Tödtmann, C. (2004): Unternehmensberater im Sonderangebot. In: Handelsblatt, 09.04.2004 (131): $\mathrm{k} 01$.

Lünendonk (2005): Führende Zeitarbeits- und Personaldienstleistungsunternehmen in Deutschland 2005, Presse-Information ZA-24-05-05. URL:

http://www.luenendonk.de/download/press/PI_ZAListe_2005_f_200505.pdf (From: 12.07.2005).

Management Angels GmbH (2004): Interimsmanagement. Für die Wirtschaft im Wandel. Hamburg.

Meinking, I. (2005): Interimsmanagement: Not am Mann? Interimsmanager als Helfer auf Zeit. In: Finance Magazin, 6/2005.

Milgrom, R./Roberts, P.(1992): Economics, Organization and Management. New Jersey: Prentice Hall, Englewood Cliffs.

Nienhüser, W./Baumhus, W. (2002): „Fremd im Betrieb“: Der Einsatz von Fremdfirmenpersonal als Arbeitskräftestrategie. In: Martin, A./Nienhüser, W. (Hrg.): Neue Formen der Beschäftigung - neue Personalpolitik? München/Mering: Rainer Hampp Verlag: 61-120.

Nienhüser, W./Matiaske, W. (2003): Der „Gleichbehandlungsgrundsatz“ bei der Leiharbeit - Entlohnung und Arbeitsbedingungen von Leiharbeitern im europäischen Vergleich. In: WSI Mitteilungen 8/2003: 466-473.

Nienhüser, W/Matiaske, W. (2006): Effects of the "Principle of Non-Discrimination" on Temporary Agency Work in 15 European Countries. In: Industrial Relations Journal, 37(1) (forthcoming).

o.V./Personalwirtschaft (1996): Unternehmensberatung. Mitgefangen - mitgehangen? In: Personalwirtschaft, 5/1996: 18-22.

o.V./Finance (2002): Raus aus der Krise -Umbauarbeiten in schwierigen Zeiten; Helfer von außen - Interimsmanager an Bord holen. In: Finance, November 2002.

o.V./Food (2003): Managers are in for the short-term, In: Food Manufacture March/2003: 54-55.

o.V./Handelsblatt (2005): Geschäft der Unternehmensberater gewinnt allmählich an Fahrt. In: Handelsblatt, 2005(33) (16.02.2005): 17.

Petmecky, A./Deelmann, T. (2004): Zur Entwicklung des Unternehmensberatungsmarktes. In: Organisationsentwicklung 2/2004: 38-43.

Pull, K. (1994): Risikoallokation im Arbeitsvertrag. In: Schreyögg, G./Conrad, P. (Hrg.): Managementforschung 4: 219-266.

Purcell, J./Purcell, K./Tailby, S. (2004): Temporary Work Agencies: Here Today, Gone Tomorrow. In: British Journal of Industrial Relations, 42(4): 705-725.

Rüpprich, B. (1997): Geschäftsführer für acht Monate. In: Personalwirtschaft, 24(8): 13-15.

Sambrook (2000): The Sambrook Report on the UK Interim Management Market in Association with the Institute of Management Consultancy and Executives Online.

Schaudwet, C. (2003): Strategieberatung. Neuer Auftritt. In: Wirtschaftswoche, 14.08.2003: 70-74.

Schwertfeger, B. (2005): Personalleiter als Manager auf Zeit. In: Personalmagazin, 6(5): 66-68.

Segal, L.M./Sullivan, D.G. (1997): The Growth of Temporary Services Work. In: Journal of Economic Perspectives, 11(2): 117-136.

Segal, L.M./Sullivan, D.G. (1998): Wage Differentials for Temporary Services Work: Evidence from Administrative Data. Working Papers Series, Research Department (WP-98-23), Federal Reserve Bank of Chicago.

Spence, M. (1973): Job Market Signaling. In: Quarterly Journal of Economics, 87: 355-374.

Streicher, H./Lünendonk, T. (2002): Lünendonk-Studie 2002: Führende Anbieter für Zeitarbeit in Deutschland. Umsätze - Themen - Strukturen - Tendenzen.

Thurn, B. (1998): Die Feuerwehr im feinen Zwirn. In: VDI-Nachrichten vom 27.11.1998; URL: http://www.vdi-nachrichten.com/vdi-Nachrichten/akutelle_ausgabe (From: 08.05.2003).

Westhoff, A. (2004): Feuerwehr für die Chefetage. In: Welt am Sonntag, 14.11.2004 (46): 12-10.

Williamson, O.E./Wachter, M.L./Harris, J.E. (1975): Understanding the Employment Relation: An Analysis of Idiosyncratic Exchange. In: Bell Journal of Economics, 6: 250-280.

Witt, F. (1987): Unternehmensführung mit Managern auf Zeit. In: Betriebswirtschaftliche Forschung und Praxis, 39(3): 288-299. 